\title{
Electrical Resistivity Tomography and TDEM Applied to Hydrogeological Study in Taubaté Basin, Brazil
}

\section{Rodrigo Corrêa Rangel1, Jorge Luís Porsani' ${ }^{1}$, Cassiano Antonio Bortolozo ${ }^{1,2}$, Luiz Rodrigo Hamada ${ }^{1}$}

${ }^{1}$ Universidade de São Paulo, Instituto de Astronomia, Geofísica e Ciências Atmosféricas, Departamento de Geofísica, São Paulo, Brazil

${ }^{2}$ CEMADEN-National Center for Natural Disaster Monitoring and Alert, General Coordination of Research and Development, São José dos Campos, Brazil

Email: rodrigo.rangel@iag.usp.br, jorge.porsani@iag.usp.br, cassianoab@gmail.com, luizhamada@iag.usp.br

How to cite this paper: Rangel, R.C., Porsani, J.L., Bortolozo, C.A. and Hamada, L.R. (2018) Electrical Resistivity Tomography and TDEM Applied to Hydrogeological Study in Taubaté Basin, Brazil. International Journal of Geosciences, 9, 119-130. https://doi.org/10.4236/ijg.2018.92008

Received: January 5, 2018

Accepted: February 23, 2018

Published: February 26, 2018

Copyright $\odot 2018$ by authors and Scientific Research Publishing Inc. This work is licensed under the Creative Commons Attribution International License (CC BY 4.0).

http://creativecommons.org/licenses/by/4.0/

\begin{abstract}
This research applies Electrical Resistivity Tomography (ERT) and Time Domain Electromagnetic Method (TDEM) to study the hydrogeology of the Taubaté basin, which is characterized by half-grabens with about $850 \mathrm{~m}$ of maximum sediments thickness. The study area is in Taubaté city, São Paulo State, Brazil, where the Taubaté aquifer is an important water source. The Taubaté Group is the main sedimentary package of the basin; it is formed mainly by shales that form aquicludes, and thin layers of sandstones that form the aquifer. There are 40 groundwater exploration wells in Taubate city that provide important information. The study purpose is to characterize the geoelectrical stratigraphy of the subsurface to locate the contact between the Quaternary and Tertiary sediments and to identify the Taubaté aquifer. The ERT is used for shallow investigations (tens of meters) and the TDEM can reach a great investigation depth (hundreds of meters). Therefore, these geophysical methods are complementary. The ERT data were acquired with the pole-dipole array with $20 \mathrm{~m}$ of electrodes spacing and $400 \mathrm{~m}$ length, and the TDEM data with the central-loop array with a $200 \times 200 \mathrm{~m}$ transmitter loop. The results permit to define the contact between the Quaternary and Tertiary sediments around $15 \mathrm{~m}$ depth, the Pindamonhangaba Formation between 15 $\mathrm{m}$ and $30 \mathrm{~m}$ depth and the Taubate Group between $30 \mathrm{~m}$ and $300 \mathrm{~m}$ depth. The TDEM method defined the Taubate Group as a single geoelectric layer because the shale and the sandstone layers are all very conductive. The basement is formed by gneiss, which is a very resistive rock. The TDEM method is not able to identify a high conductor/resistor contrast. Overall, the results are
\end{abstract}


consistent with the known geology and the wells information.

\section{Keywords}

Electrical Resistivity Tomography (ERT), Time Domain Electromagnetic (TDEM), Hydrogeophysics, Taubaté Basin, Brazil

\section{Introduction}

In this research, the electrical resistivity tomography (ERT) and time domain electromagnetic (TDEM) methods were applied to a hydrogeological study in Taubaté basin, São Paulo State, Brazil (Figure 1), where the Taubaté aquifer is an important water supply for the region.

Each method has advantages and limitations in terms of investigation depth and resolution. The ERT method is normally used in shallow investigations (tens of meters) due to logistical limitation because it requires a long aperture to achieve greater depths. On the other hand, the TDEM method has a low resolution for the shallow layers; it is used in deep investigations (hundreds of meters) and can define conductive layers [1] [2].

Both methods are widely applied in hydrogeophysical studies, because of rapid data acquisition, relatively low cost, and reliability. They have the potential to identify aquifers, aquicludes, and aquitards, which normally, in Brazil, are more conductive than the surrounding layers. They are also sensitive to geological properties, like clay content.

Electrical resistivity method [3] [4] [5] [6] and TDEM [7]-[18] have been successfully applied individually and also jointly [19] [20] [21] [22] [23] for hydrogeophysical investigations in many places around the world, including Brazil [11] [13] [14] [16] [17] [19] [21] [22]. Their applications also include mining, geotechnical and environmental studies [24] [25], among others.

The study aims to characterize the geoelectrical stratigraphy of the subsurface to locate the contact of the Quaternary and Tertiary sediments and identify the Taubaté aquifer. Furthermore, it aims to contribute to the geoelectrical methods interpretation in a hydrogeological context like Taubaté basin and to collaborate with the hydrogeophysical studies in São Paulo State.

\section{Study Area}

The studied area is in Taubaté city, São Paulo State, Brazil, which is located on the central portion of the Taubaté Basin (Figure 1(a)). Taubaté is a medium-sized city with about 308,000 inhabitants, where the demand for water has been increasing.

The data acquisitions were conducted on a cattle farm around $6 \mathrm{~km}$ from the city center. The terrain was practically flat, which has the advantage of not requiting topography correction on data processing. 


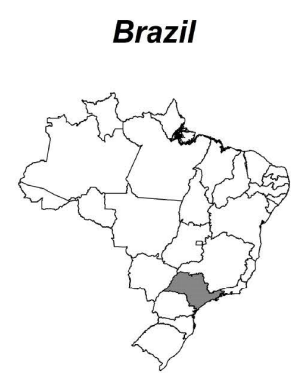

- Wells

* Taubaté City

จ São Paulo City

- Study Area

$\square \quad$ Taubaté Basin
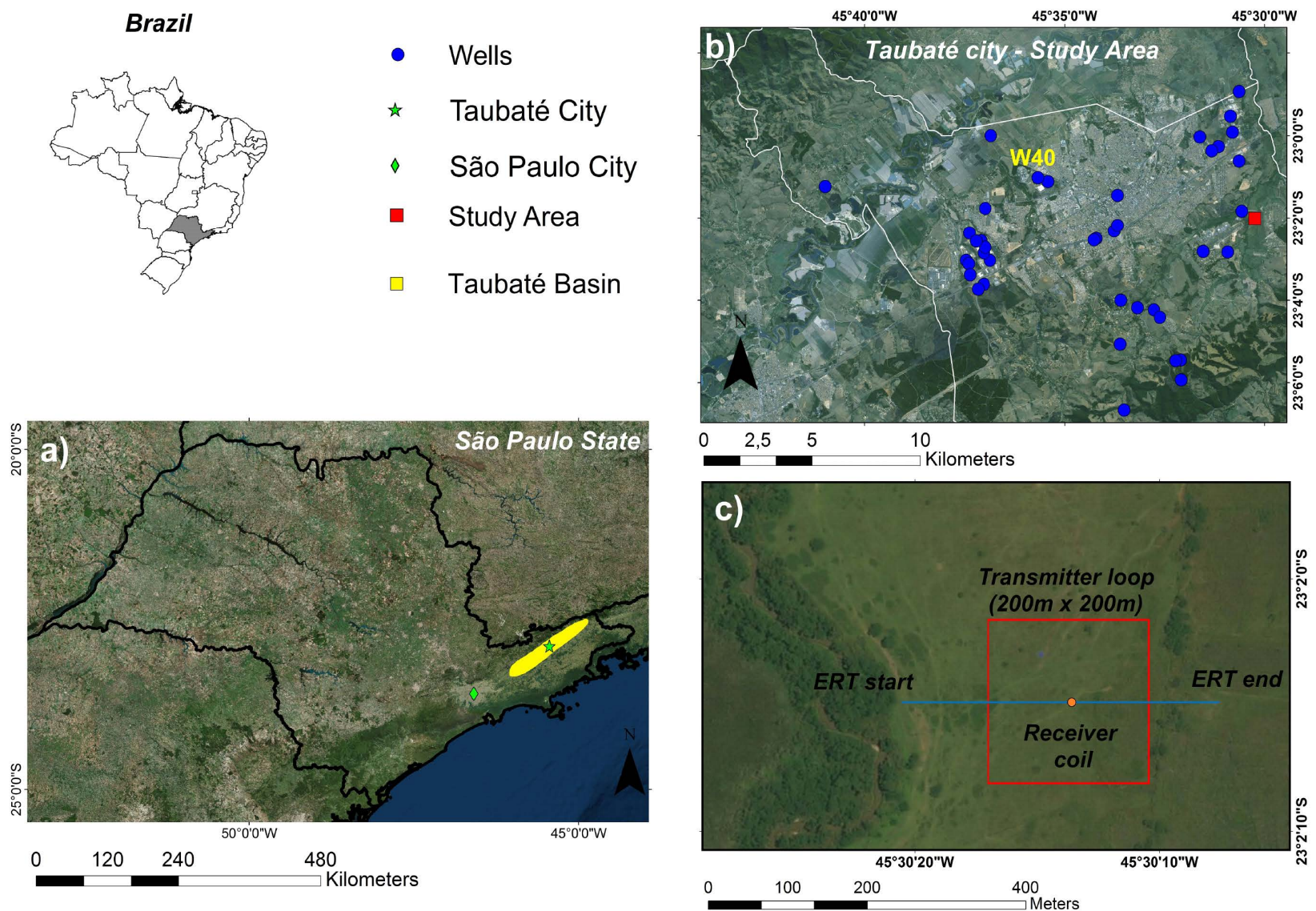

Figure 1. Study area location. (a) Taubaté Basin and Taubaté city, São Paulo state, Brazil; (b) Study area and wells (40); (c) ERT line and TDEM loop.

\subsection{Geological Setting}

According to [26], Taubaté basin is the largest basin of the Continental Rift of Southeast Brazil (CRSB) with $170 \mathrm{~km}$ length and $20 \mathrm{~km}$ width. The basin is elongated in NE-SW direction and presents normal faults in NW-SE direction. The basin is related to Tertiary extensional tectonics and it is characterized by a series of half-grabens with $850 \mathrm{~m}$ of maximum sediments thickness [27].

Figure 2 presents a geological map and the stratigraphic chart of the basin. It was developed over Precambrian gneisses and granites [28]. The sedimentary fill is basically continental and can be divided in two phases: the first, syntectonic to the rift, with the deposition of the Taubaté Group; and the second, posterior to diastrophic tectonics, with the deposition of the Pindamonhangaba Formation and alluvial and colluvial deposits [28].

The main sedimentary package is the Taubate Group, which is subdivided by the Resende, Tremembé and São Paulo formations. Taubaté Group is formed mainly by shales and sandstones. Resende Formation is the most abundant package of the Taubaté Group [27]. Pindamonhangaba Formation was deposited in the Neogene in a fluvial meandering environment. Finally, in the Quaternary, there are alluvial, colluvial, colluvial-alluvial and talus deposits. 


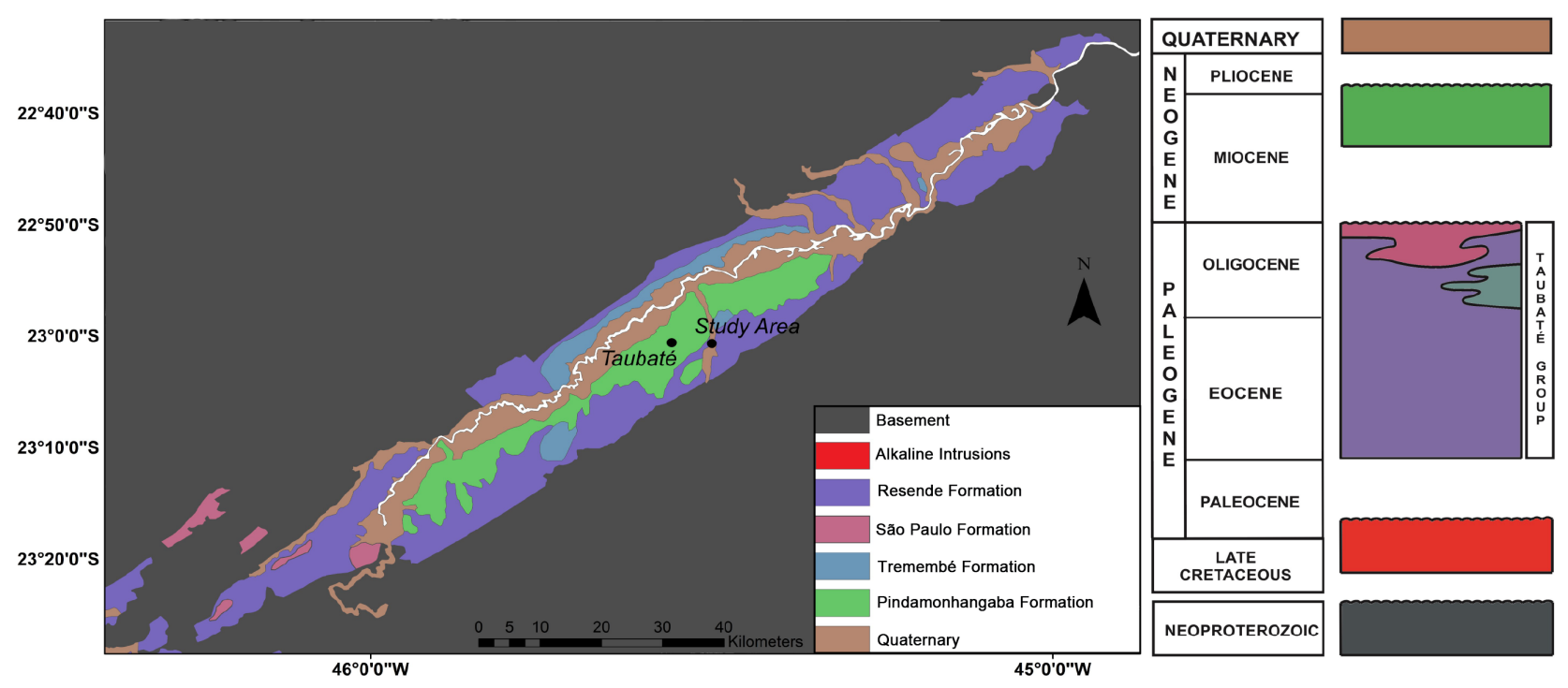

Figure 2. Geological map and stratigraphic chart of Taubaté basin (adapted from [27]).

\subsection{Taubaté Aquifer}

Taubate Aquifer occurs mainly in two areas of the basin, in the southwest and in the northeast. Between these two regions, where Taubate city is located, there is a compartment filled predominantly by argillites and shales with low permeability, which presents aquiclude characteristics [29]. As a result of its depositional environments, the aquifer is a multilayer type, with alternation of sandy or aquifer layers, associated with fluvial facies, and clayey or confining layers, associated with lacustrine or floodplain facies [29]. In Taubaté city, the saturated thickness of the aquifer varies from $200 \mathrm{~m}$ to $300 \mathrm{~m}$. According to [30], the central region of the basin, where Taubaté is located, presents unfavorable characteristics for groundwater exploration, with flow rates lower than $10 \mathrm{~m}^{3} / \mathrm{h}$.

\subsection{Wells}

There are 40 wells in Taubaté city available in the Groundwater Information System (SIAGAS) of the Geological Service of Brazil (CPRM) [31] database, which include the coordinates, depth, water use and a geological profile for each well. Figure 1(b) shows the location of the wells. All wells are tubular and the water is mainly used for domestic or industrial supply. Some of them present the water level and flow rate, which in general are lower than $10 \mathrm{~m}^{3} / \mathrm{h}$, being consistent with [30]. Six wells reached the basement depth, which is formed by gneisses.

The closest well is around $750 \mathrm{~m}$ distant and the deepest (W40) (that reaches $650 \mathrm{~m}$ depth) is around $9.5 \mathrm{~km}$ distant from the study area. Table 1 shows W40 lithological description. Down to $11 \mathrm{~m}$ depth represents the Quaternary sediments. The sandstone between $11 \mathrm{~m}$ and $16 \mathrm{~m}$ depth probably represents the Pindamonhangaba formation. The rocks between 16 and $510 \mathrm{~m}$ depth represent the Taubaté Group, which is formed mainly by shales, and bellow $510 \mathrm{~m}$ depth is the basement formed by gneisses. 
Table 1. Lithological description of the deepest well (W40) in Taubaté city [31].

\begin{tabular}{ccc}
\hline From $(\mathrm{m})$ & To $(\mathrm{m})$ & Soil/Lithology \\
\hline 0 & 4 & Soil \\
4 & 11 & Clay \\
11 & 16 & Sandstone \\
16 & 485 & Shales \\
485 & 493 & Clayey sandstone \\
493 & 510 & Shales \\
510 & 650 & Gneiss \\
\hline
\end{tabular}

In general, from all wells lithological descriptions, the Taubaté Group is formed mainly by shales intercalated with thin layers of sandstones. Therefore, in the Taubaté Group, the shales form aquicludes and the sandstones form the aquifer.

\section{Geophysical Methods}

In this research were applied two geophysical methods: Electrical Resistivity Tomography (ERT) and Time Domain Electromagnetic (TDEM). Both methods investigate the same physical property of subsurface materials, the electrical resistivity $(\rho)$.

In the ERT method, the investigation is done through the injection of electric currents and, in the TDEM method, through the electromagnetic induction in conductive materials in the subsurface. Both methods use artificial sources and the response is measured at the surface. Thus, it is possible to relate the electrical resistivity distribution with the geology or variations in the lithological composition, for example, the presence of water, fractures, and mineralogy.

\subsection{Electrical Resistivity Tomography (ERT)}

The ERT method consists of injecting an electric current $(I)$ into the ground through metallic electrodes and measuring the resulting potential $(\Delta V)$ by other electrode pairs. In this way, it is possible to obtain the electrical resistivity distribution of the subsurface.

Electrical resistivity values can be estimated because the spatial arrangement of the electrodes is known. According to [32], the apparent electrical resistivity $\left(\rho_{a}\right)$ is given by:

$$
\rho_{a}=K \frac{\Delta V}{I}
$$

where $K$ is the geometric factor, which depends on the electrodes array. The investigation depth depends on the subsurface resistivity and the electrodes separation, i.e., greater depths are achieved by increasing the array size.

The ERT is used to map the lateral variation of the resistivity as a function of depth (2D). There are several types of electrode arrays, however, in this research 
was only used the Pole-Dipole array with six investigation levels.

The ERT data was acquired in June 2016 with the Syscal Pro (Iris Instruments) equipment. The imaging line was $400 \mathrm{~m}$ length (Figure $1(\mathrm{c})$ ) and with 20 $\mathrm{m}$ of electrodes spacing. The data were inverted with the RES2DINV software [33], which uses the field data to automatically determine a two-dimensional model of the subsurface resistivity.

\subsection{Time Domain Electromagnetic (TDEM)}

The TDEM method is based on the electromagnetic induction principle and it is used to estimate the resistivity variation as a function of depth [1] [2]. The investigation is performed by measuring the decay of an induced secondary magnetic field in the subsurface due to the variation of a primary magnetic field generated on the surface.

According to [2], the relationship between the secondary magnetic field variation $\left(\partial B_{z} / \partial t\right)$ and the apparent resistivity $\left(\rho_{a}\right)$ is given by:

$$
\rho_{a}=\frac{1}{\pi}\left(\frac{I \pi a^{2}}{20 \partial B_{z} / \partial t}\right)^{2 / 3}\left(\frac{\mu_{0}}{t}\right)^{5 / 3}
$$

where $I(\mathrm{~A})$ is current, $a(\mathrm{~m})$ the loop radius, $\mu_{0}$ the vacuum magnetic permeability and $t(\mathrm{~s})$ the time.

There are several acquisition arrays and field procedures. The array configuration, size, and other parameters depend on the purpose of the research. In this research, the central loop array (Figure 1(c)) was used, where the receiver coil is placed in the transmitter loop center. It is one of the most popular TDEM arrays, having the advantage of a good signal-to-noise ratio.

The TDEM method is sensitive to conductive layers, because of the current flows that are induced in these layers. The investigation depth depends on the subsurface resistivity, the more resistive the medium, the faster the secondary field diffuses and vice versa [2]. The investigation depth also depends on the magnetic dipole moment ( $M=I A$ ) of the transmitter loop. Therefore, increasing $M$, it is possible to reach greater investigation depths. In this research, the acquisition was done with $I=17.5 A$ and $200 \times 200 \mathrm{~m}$ square transmitter loop (Figure 1(c)).

This method has an insignificant influence from natural sources noise. The main noise sources are man-made artifacts such as power transmission lines, cables and buried pipes and metal fences near the data acquisition area [2]. The transmitter induces electric currents in these conductors which, as consequence, interfere in the induced secondary currents in subsurface materials. No noise source influenced the acquisition, because the electric power lines and metal fences were more than $100 \mathrm{~m}$ away, which is considered a safe distance [2].

The data were acquired in April 2016 with the PROTEM 57-MK2 D [34] equipment, which consists of a transmitter that is connected to a power generator to produce the primary electromagnetic field; and a $3 \mathrm{D}$ receiver coil of about $1 \mathrm{~m}$ diameter and $200 \mathrm{~m}^{2}$ of effective area that is connected to a computer to 
record the signal of the secondary electromagnetic field induced in the subsurface. The main acquisition parameters were: repetition rates of $30 \mathrm{~Hz}, 7.5 \mathrm{~Hz}$ and $3 \mathrm{~Hz}$, integration time of $30 \mathrm{~s}$ and average of three points measured for each repetition rate.

The data were inverted with the Curupira software [35]. The inversion process consists of determining the electrical resistivity and thickness of the subsurface layers from the measured data.

\section{Results Analysis}

Figure 3 shows the ERT inversion result, where: a) the measured apparent resistivity pseudosection, b) the calculated apparent resistivity pseudosection and c) the inverted geoelectric model. The RMS error is $1.59 \%$ after 6 iterations. The black line in the inverted model (Figure 3(c)) represents the contact between the Quaternary and Tertiary sediments. The Quaternary sediments are formed by soil, alluvial and colluvial deposits going down to maximum around $30 \mathrm{~m}$ depth in the left side; it is a very resistive zone, with the resistivity varying from more than $200 \Omega \cdot \mathrm{m}$ to $80 \Omega \cdot \mathrm{m}$. Below that, the Pindamonhangaba Formation is formed by sandstones and presents resistivity between the $80 \Omega \cdot \mathrm{m}$ and $30 \Omega \cdot \mathrm{m}$. The white line represents the interface between the Pindamonhangaba formation and the Taubaté Group, which is very conductive, between $30 \Omega \cdot \mathrm{m}$ and 10 $\Omega \cdot \mathrm{m}$.

Figure 4 shows the TDEM inversion result. Figure 4(a) presents the apparent resistivity $(\Omega \cdot \mathrm{m})$ versus time $(\mathrm{ms})$ showing the measured data and the adjusted curve; and Figure 4(b), the inverted geoelectric model, depth (m) versus resistivity $(\Omega \cdot \mathrm{m})$. The adjustment error is $1.7 \%$ after 1000 iterations.

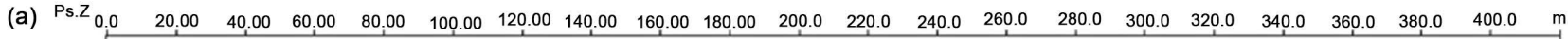

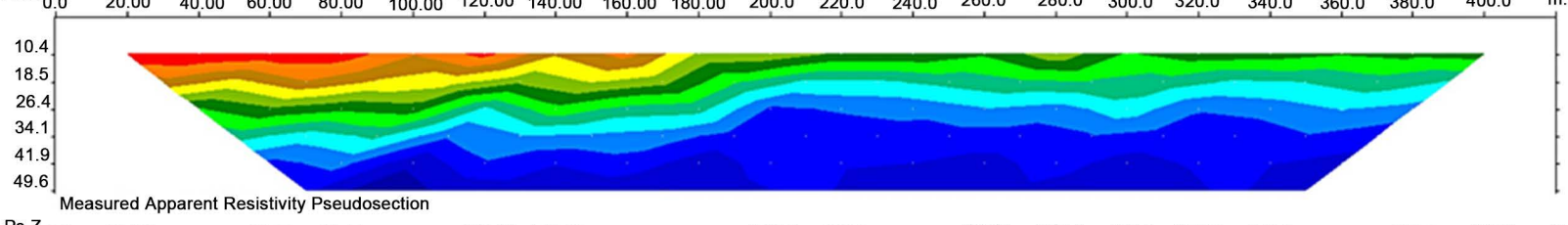

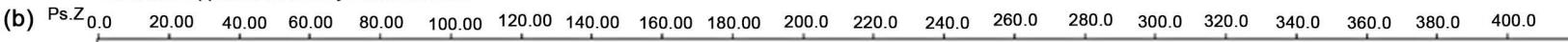

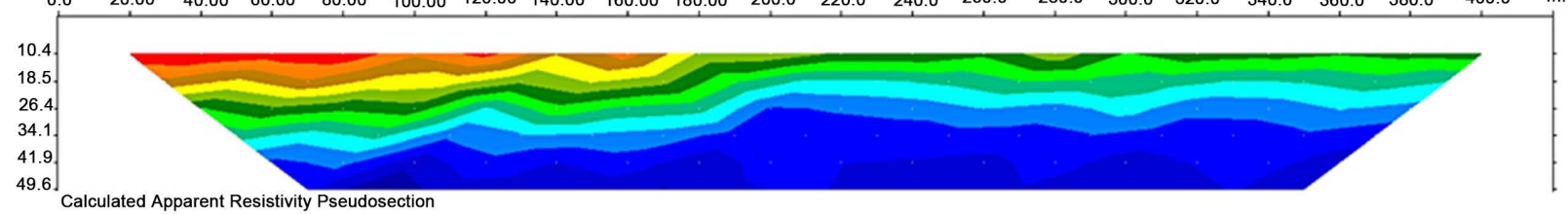

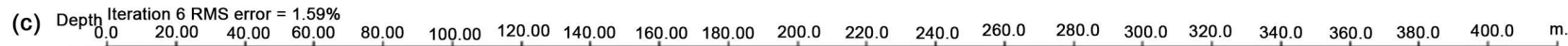

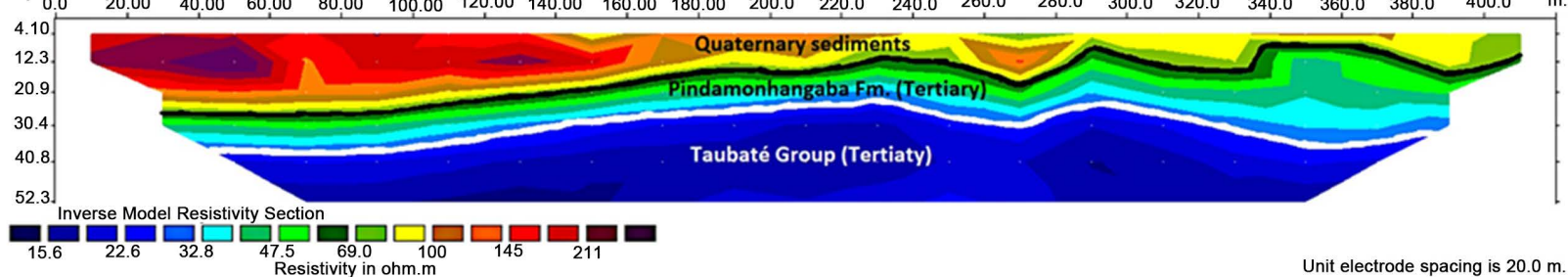

Figure 3. ERT inversion result. (a) Measured apparent resistivity pseudosection; (b) Calculated apparent resistivity pseudosection; c) Inverted geoelectric model. 
(a)

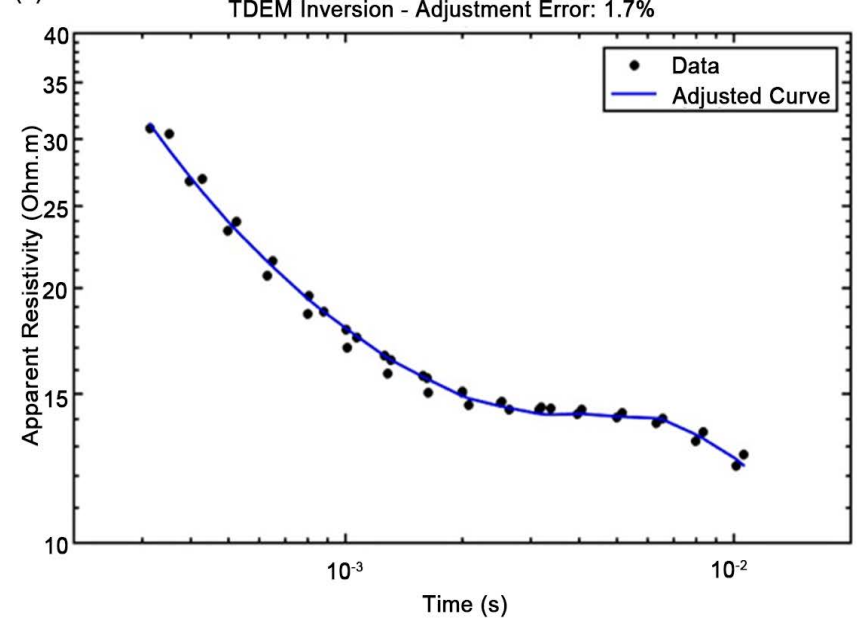

(b)

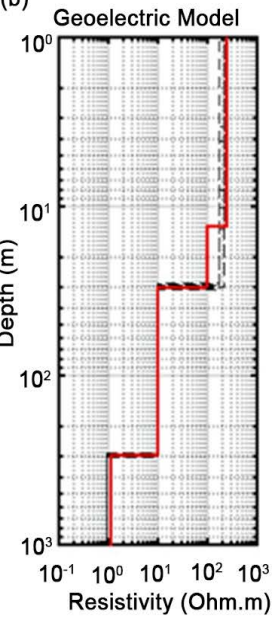

Figure 4. TDEM inversion result. (a) Feild data points with the adjusted curve on Curupira software; (b) The inverted geoelectric model.

In the geoelectric model, there are 3 geoelectrical layers down to $300 \mathrm{~m}$ depth. The first layer down to $13 \mathrm{~m}$ is resistive, with more than $200 \Omega \cdot \mathrm{m}$, representing the Quaternary sediments. The second layer, from $13 \mathrm{~m}$ to $30 \mathrm{~m}$ depth, has a resistivity around $100 \Omega \cdot \mathrm{m}$, which represent the Pindamonhangaba formation. The third layer, from $30 \mathrm{~m}$ to around $300 \mathrm{~m}$ is very conductive, around $10 \Omega \cdot \mathrm{m}$, representing the Taubaté Group. The TDEM result is consistent with the ERT result.

The Taubate Group is very conductive, therefore the signal concentrates and dissipates in this layer, not being able to induce an electromagnetic field in the layer below, which is the resistive basement. The basement is formed by gneisses, which is a very resistive rock, with resistivity values in the order of thousands of $\Omega \cdot \mathrm{m}[36]$.

Table 2 summarizes the ERT and TDEM results interpretation. The first layer is interpreted as the Quaternary sediments, the second layer is the Pindamonhangaba formation and the third layer represents the Taubate Group. The resistivity values were estimated based on the ERT (Figure 3(c)) and the TDEM (Figure 4(b)) inverted geoelectric models. These results are coherent and they agree with wells information.

\section{Conclusions}

The results have shown a great potential for the application of the combined ERT and TDEM methods to the geoelectrical characterization of the Taubaté Basin, making it possible to identify the contact between the Quaternary and Tertiary sediments and to define the Taubaté Group, which stores the Taubaté aquifer.

Both data inversions obtained a low RMS error $(<2 \%)$, resulting in a geoelectrical model coherent with the known geology. 
Table 2. Interpretation of the ERT and TDEM inverted geoelectric models.

\begin{tabular}{cccc}
\hline Depth $(\mathrm{m})$ & Resistivity $(\Omega \cdot \mathrm{m})$ & Interpretation & Period/Epoch \\
\hline $0-15$ & $250-100$ & Soil, alluvial and colluvial deposits & Quaternary \\
$15-30$ & $100-30$ & Pindamonhangaba Formation & Neogene \\
$30-300$ & $30-10$ & Shales and sandstones (Taubaté Group) & Eocene-Oligocene \\
\hline
\end{tabular}

The ERT was able to image the shallow sedimentary layers until $50 \mathrm{~m}$ depth and the TDEM provided information until about $300 \mathrm{~m}$ depth, allowing defining the conductive layer represented by the Taubaté Group.

The Taubaté Group is approximately $270 \mathrm{~m}$ thick, mainly formed by shale and thin sandstone layers. The shales form the aquiclude and the sandstones form the aquifer. Both are very conductive, so the TDEM method identified them as a single conductive layer.

The Taubaté Group is a very conductive layer and, below it, the basement is very resistive. Therefore, in this research, the TDEM method was not able to pass through the sedimentary conductive layer; however, based on the well information, the basement top is probably around $300 \mathrm{~m}$ depth, but more studies are needed.

Both geophysical methods have the advantage of rapid data acquisition, relatively low cost, and they are reliable to identify aquifers and aquicludes. Other geophysical studies have already been done in Taubaté basin. For example, Cogné et al. [37] have reinterpreted 11 seismic profiles of the basin to study its tectonic setting; and Padilha et al. [38] have applied the magnetotelluric method across the basin to obtain a deep $(20 \mathrm{~km}) 2 \mathrm{D}$ geoelectrical model, which identified the conductive sediments of Taubaté Group with low resolution. However, the present research is the first in terms of a hydrogeophysical study in Taubate basin.

\section{Acknowledgements}

RCR and LRH thank CAPES (Coordenação de Aperfeiçoamento de Pessoal de Nível Superior) for providing the research scholarships. JLP thanks to FAPESP (Fundação de Amparo à Pesquisa do Estado de São Paulo) (grants: 2009/08466-3 and 2012/15338-4) and CNPq (Conselho Nacional de Desenvolvimento Científico e Tecnológico) (grants: 301692/2013-0 and 406653/2013-5), both for providing financial support to develop this research. $\mathrm{CAB}$ thanks to CNPq for the Postdoctoral scholarship (150230/2016-8). We thank IAG/USP for providing the infrastructure support. We thank Ernande Costa Santos, Marcelo Cesar Stangari and the students for helping in geophysical data acquisition.

\section{References}

[1] McNeill, J.D. (1994) Principles and Application of Time Domain Electromagnetic Techniques for Resistivity Sounding. Technical Note TN-27, Geonics Ltd., Ontario.

[2] Christiansen, A.V., Auken, E. and Sørensen, K. (2006) The Transient Electromag- 
netic Method. In: Kirsch, R., Ed., Groundwater Geophysics-A Tool for Hydrogeology, GSW Ltd., Aarhus, 179-225. https://doi.org/10.1007/3-540-29387-6_6

[3] Froese, D.G., Smith, D.G. and Clement, D.T. (2005) Characterizing Large River History with Shallow Geophysics: Middle Yukon River, Yukon Territory and Alaska. Geomorphology, 67, 391-406.

https://doi.org/10.1016/j.geomorph.2004.11.011

[4] Chandra, S., Rao, V.A., Krishnamurthy, N.S., Dutta, S. and Ahmed, S. (2006) Integrated Studies for Characterization of Lineaments Used to Locate Groundwater Potential Zones in a Hard Rock Region of Karnataka, India. Hydrogeology Journal, 14, 767-776. https://doi.org/10.1007/s10040-005-0480-3

[5] Fowler, D.E. and Moysey, S.M.J. (2011) Estimation of Aquifer Transport Parameters from Resistivity Monitoring Data within a Coupled Inversion Framework. Journal of Hydrology, 409, 545-554. https://doi.org/10.1016/j.jhydrol.2011.08.063

[6] Yeh, H.F., Lin, H.I., Wu, C.S., Hsu, K.C., Lee, J.W. and Lee, C.H. (2015) Electrical Resistivity Tomography Applied to Groundwater Aquifer at Downstream of Chih-Ben Creek Basin, Taiwan. Environmental Earth Sciences, 73, 4681-4687. https://doi.org/10.1007/s12665-014-3752-1

[7] Fitterman, D.V. and Stewart, M.T. (1986) Transient Electromagnetic Sounding for Groundwater. Geophysics, 51, 955-1005. https://doi.org/10.1190/1.1442158

[8] Goldman, M., Du Plooy, A. and Eckard, M. (1994) On Reducing Ambiguity in the Interpretation of Transient Electromagnetic Sounding Data. Geophysical Prospecting, 42, 3-25. https://doi.org/10.1111/j.1365-2478.1994.tb00192.x

[9] Danielsen, J.E., Auken, E., Jorgensen, F., Sondergaard, V. and Sørensen, K.I. (2003) The Application of the Transient Electromagnetic Method in Hydrogeophysical Surveys. Journal of Applied Geophysics, 53, 181-198. https://doi.org/10.1016/j.jappgeo.2003.08.004

[10] Jørgensen, F., Sandersen, P.B.E. and Auken, E. (2003) Imaging Buried Quaternary Valleys Using Transient Electromagnetic Method. Journal of Applied Geophysics, 53, 199-213. https://doi.org/10.1016/j.jappgeo.2003.08.016

[11] Carrasquilla, A.A.G. and Ulugergerli, E. (2006) Evaluation of the Transient Electromagnetic Geophysical Method for Stratigraphic Mapping and Hydrogeological Delineation in Campos Basin, Brazil. Revista Brasileira de Geofísica, 24, 333-341. https://doi.org/10.1590/S0102-261X2006000300003

[12] Nielsen, L., Jørgensen, N.O. and Gelting, P. (2007) Mapping of the Freshwater Lens in a Coastal Aquifer on the Keta Barrier (Ghana) by Transient Electromagnetic Soundings. Journal of Applied Geophysics, 62, 1-15. https://doi.org/10.1016/j.jappgeo.2006.07.002

[13] Porsani, J.L., Bortolozo, C.A., Almeida, E.R., Sobrinho, E.N.S. and Santos, T.G. (2012) TDEM Survey in Urban Environmental for Hydrogeological Study at USP Campus in São Paulo City, Brazil. Journal of Applied Geophysics, 76, 102-108. https://doi.org/10.1016/j.jappgeo.2011.10.001

[14] Porsani, J.L., Almeida, E.R. and Bortolozo, C.A. (2012) TDEM Survey in an Area of Seismicity Induced by Water Wells in Paraná Sedimentary Basin, Northern São Paulo State, Brazil. Journal of Applied Geophysics, 82, 75-83. https://doi.org/10.1016/j.jappgeo.2012.02.005

[15] Martínez-Moreno, F.J., Santos, F.A.M., Madeira, J., Bernardo, I., Soares, A., Esteves, M. and Adão, F. (2016) Water Prospection in Volcanic Islands by Time Domain Electromagnetic (TDEM) Surveying: The Case Study of the Islands of Fogo and Santo Antão in Cape Verde. Journal of Applied Geophysics, 134, 226-234. 
https://doi.org/10.1016/j.jappgeo.2016.09.020

[16] Almeida, E.R., Porsani, J.L., dos Santos, F.A.M. and Bortolozo, C.A. (2017) 2D TEM Modeling for a Hydrogeological Study in the Paraná Sedimentary Basin, Brazil. International Journal of Geosciences, 8, 693-710. https://doi.org/10.4236/ijg.2017.85038

[17] Campaña, J.D.R., Porsani, J.L., Bortolozo, C.A., Oliveira, G.S. and Santos, F.A.M. (2017) Inversion of TEM Data and Analysis of the 2D Induced Magnetic Field Applied to the Aquifers Characterization in the Paraná Basin, Brazil. Journal of Applied Geophysics, 138, 233-244. https://doi.org/10.1016/j.jappgeo.2017.01.024

[18] Costabel, S., Siemon, B., Houben, G. and Günther, T. (2017) Geophysical Investigation of a Freshwater Lens on the Island of Langeoog, Germany-Insights from Combined HEM, TEM and MRS Data. Journal of Applied Geophysics, 136, 231-245. https://doi.org/10.1016/j.jappgeo.2016.11.007

[19] Meju, M.A., Fontes, S.L., Oliveira, M.F.B., Lima, J.P.R., Ulugergerli, E.U. and Carrasquilla, A.A.G. (1999) Regional Aquifer Mapping using Combined VES-TEMAMT-EMAP Methods in the Semi-Arid Eastern Margin of Parnaiba Basin, Brazil. Geophysics, 64, 337-356. https://doi.org/10.1190/1.1444539

[20] Albouy, Y., Andrieux, P., Rakotondrasoa, G., Ritz, M., Descloitres, M., Join, J.L. and Rasolomanana, E. (2001) Mapping Coastal Aquifers by Joint Inversion of DC and TEM Soundings-Three Case Histories. Ground Water, 39, 87-97. https://doi.org/10.1111/j.1745-6584.2001.tb00354.x

[21] Bortolozo, C.A., Porsani, J.L., Santos, F.A.M. and Almeida, E.R. (2015) VES/TEM 1D Joint Inversion by Using Controlled Random Search (CRS) Algorithm. Journal of Applied Geophysics, 112, 157-174. https://doi.org/10.1016/j.jappgeo.2014.11.014

[22] Bortolozo, C.A., Couto, M.A., Porsani, J.L., Almeida, E.R. and Santos, F.A.M. (2014) Geoelectrical Characterization Using Joint Inversion of VES/TEM Data: A Case Study in Paraná Sedimentary Basin, São Paulo State, Brazil. Journal of Applied Geophysics, 111, 33-46. https://doi.org/10.1016/j.jappgeo.2014.09.009

[23] Martínez-Moreno, F.J., Santos, F.A.M., Bernardo, I., Farzamian, M., Nascimento, C., Fernandes, J., Casal, B. and Riberio, J.A. (2017) Identifying Seawater Intrusion in Coastal Areas by Means of $1 \mathrm{D}$ and quasi-2D Joint Inversion of TDEM and VES Data. Journal of Hydrology, 552, 609-619. https://doi.org/10.1016/j.jhydrol.2017.07.026

[24] Schmutz, M., Albouy, Y., Guerin, R., Maquaire, O., Vassal, J., Schott, J.J. and Descloitres, M. (2000) Joint Electrical and Time Domain Electromagnetism (TDEM) Data Inversion Applied to the Super Sauze Earthflow (France). Surveys in Geophysics, 21, 371-390. https://doi.org/10.1023/A:1006741024983

[25] Schmutz, M., Guérin, R., Andrieux, P. and Maquaire, O. (2009) Determination of the 3D Structure of an Earthflow by Geophysical Methods: The Case of Super Sauze, in the French Southern Alps. Journal of Applied Geophysics, 68, 500-507. https://doi.org/10.1016/j.jappgeo.2008.12.004

[26] Riccomini, C., Sant'Anna, L.G. and Ferrari, A.L. (2004) Evolução geológica do Rift Continental do Sudeste do Brasil. In: Mantesso Neto, V., Bartorelli, A., Carneiro, C.D.R. and Brito-Neves, B.B., Eds., Geologia do Continente Sul-Americano: Evolução da Obra de Fernando Flávio Marques de Almeida, Ed. Beca, São Paulo, 383-405.

[27] Marques, A. (1990) Evolução tectono-sedimentar e perspectivas exploratórias da Bacia de Taubaté, São Paulo, Brasil. Boletim de Geociências da Petrobrás, 4, 253-262. 
[28] Riccomini, C. (1989) O Rift Continental do Sudeste do Brasil. PhD Thesis, Institute of Geosciences, University of São Paulo, São Paulo.

[29] DAEE (Departamento de Águas e Energia Elétrica) (1977) Estudo de águas subterrâneas da região administrativa 3 (São José dos Campos e Faixa Litorânea). Governo do Estado de São Paulo. São Paulo.

[30] DAEE (Departamento de Águas e Energia Elétrica), IG (Instituto Geológico), IPT (Instituto de Pesquisas Tecnológicas) and CPRM (Serviço Geológico do Brasil) (2005) Mapa de águas subterrâneas do Estado de São Paulo. São Paulo.

[31] Groundwater Information System (SIAGAS) of the Geological Service of Brazil (CPRM). http://siagasweb.cprm.gov.br/layout/

[32] Koefoed, O. (1979) Geosounding Principles 1: Resistivity Sounding Measurements. Elsevier Science Publishing Company, Amsterdam.

[33] Loke, M.H. (2004) Res2Dinv v. 3.54 for Windows 98/Me/2000/NT/XP. Rapid 2D Resistivity and IP Inversion Using the Least-Squares Method. Software Manual.

[34] Geonics (2009) PROTEM 57-MK2 D Operating Manual. Geonics Limited, Mississauga, Ontario.

[35] Bortolozo, C.A. and Porsani, J.L. (2012) "CURUPIRA V1.0". Software de inversão conjunta 1D de sondagens SEV/TDEM. Registro de Programa de Computador número 12988-1. Revista da Propriedade Industrial, 2165, 145.

[36] Telford, W.M., Geldart, L.P. and Sheriff, R.E. (1990) Applied Geophysics. 2nd Edition, Cambridge University Press, Cambridge. https://doi.org/10.1017/CBO9781139167932

[37] Cogné, N., Coboold, P.R., Riccomini, C. and Gallagher, K. (2013) Tectonic Setting of the Taubaté Basin (Southeastern Brazil): Insights from Regional Seismic Profiles and Outcrop Data. Journal of South American Earth Sciences, 42, 194-204. https://doi.org/10.1016/j.jsames.2012.09.011

[38] Padilha, A.L., Vitorello, I. and Brito, P.M.A. (2002) Magnetotelluric Soundings across the Taubaté Basin, Southeast Brazil. Earth, Planets and Space, 54, 617-627. https://doi.org/10.1186/BF03353050 